\title{
The Effects of Inoculation with Three Glomus Species on Growth and Pb Uptake by Hemp (Cannabis Sativa) in a Pb-Contaminated Soil
}

\author{
Roya Zalaghi $^{1^{*}}$, Ali-Akbar Safari-Sinegani ${ }^{2}$, Nasser Aliasgharzad ${ }^{3}$ (1) \\ ${ }^{1}$ Department of Soil Science, Faculty of Agriculture, Shahid Chamran University of Ahvaz, Iran \\ ${ }^{2}$ Department of Soil Science, Faculty of Agriculture, Bu Ali Sina University, Hamedan, Iran \\ ${ }^{3}$ Department of Soil Science, Faculty of Agriculture, University of Tabriz, Iran \\ E-mail: r.zalaghi@scu.ac.ir
}

Received: 31 December 2019; Revised: 26 March 2020; Accepted: 26 March 2020

\begin{abstract}
Increasing levels of hazardous heavy metals, which enter soil and water ecosystems have had a detrimental effect on global living organisms and needs special attention. The effect of inoculation with three Glomus mycorrhizal fungi (G.mosseae, G.etunicatum and G.constrictum) on hemp growth and some biological properties was evaluated in a soil contaminated with different levels of lead $\left(0,600,1200\right.$ and $1800 \mathrm{mg} \cdot \mathrm{kg}^{-1} \mathrm{~Pb}$ soil) in the form of $\mathrm{Pb}\left(\mathrm{NO}_{3}\right)_{2}$. The results show that shoot and root dry weights decreased with increasing Pb levels in soil. But $\mathrm{Pb}$ concentration in roots and shoots of hemp increased significantly with increasing $\mathrm{Pb}$ levels in soil. However the growth of mycorrhizal inoculated hemps was significantly higher than that of non-inoculated hemp. Mycorrhizal inoculation increased the concentration of $\mathrm{Pb}$ in the shoot and root of hemp. In this study, both translocation factor (TF) and enrichment factor (EF) were $<1$ and decreased with increasing $\mathrm{Pb}$ concentration in soil. The TF was higher in non-inoculated hemp than inoculated hemps. It shows the inhibition effect of mycorrhiza in translocation of $\mathrm{Pb}$ from root to shoot. The EF of all inoculated hemps $(0.18)$ was significantly greater than non-inoculated hemp (0.17), showing increased uptake of $\mathrm{Pb}$ due to inoculation with mycorrhiza. Simple linear regressions show that the diethylenetriaminepentaacetic acid (DTPA) extractable $\mathrm{Pb}$ is more suitable index for evaluating the toxicity effect of soil $\mathrm{Pb}$ than the total $\mathrm{Pb}$ content.
\end{abstract}

Keywords: $\mathrm{Pb}$ pollution, phytoremediation, mycorrhiza, hemp

\section{Introduction}

Lead $(\mathrm{Pb})$ compounds, originate mainly from weathering, industries, storage batteries, vehicle fumes, metalplating factories, mining and smelting of $\mathrm{Pb}$ ores, $\mathrm{Pb}$-containing pigments, fertilizers, pesticides, sewage sludges, explosives, additives and gasoline [1-2], all of which are regarded as a principal source of environmental contamination [3]. Contaminated soils contain $\mathrm{Pb}$ in the range of $400-800 \mathrm{mg} \cdot \mathrm{kg}^{-1}$ soil, although in industrialised areas, this level may reach $1000 \mathrm{mg} \cdot \mathrm{kg}^{-1}$ soil [4-5].

There are various methods for cleaning of environment from heavy metals. The application of biological methods, including plant bioremediation and use of microorganisms, has been proven to be more effective and less expensive [6-7].

Arbuscular mycorrhizal (AM) fungi are developing symbiosis with the most of the plants and are occurring in almost all soils [8]. Numerous research works have indicated that arbuscular mycorrhizal (AM) can benefit their host

Copyright (C2020 Roya Zalaghi, et al.

DOI: https://doi.org/10.37256/sbe.112021192

This is an open-access article distributed under a CC BY license

(Creative Commons Attribution 4.0 International License)

https://creativecommons.org/licenses/by/4.0/ 
plant nutrition and enhance plant tolerance of heavy metal pollution [9-11] by several mechanisms, including extra-and intracellular precipitation, sequestration and biosorption to the cell wall [12].

While some researchers reported that the inoculation with mycorrhizal fungus resulted to an increased uptake of the heavy metals by plants and its transfer from roots to shoots tissues [13-14], others reporters indicated that it led to reduction in the uptake of heavy elements by plants [15] or stabilization of heavy metals within roots [16-18].

Although, AM fungi usually can enhance plant resistance to heavy metals [19-22], but selection of autochthonous AM species from heavy metal contaminated areas that are adapted to this conditions, can be more beneficial [23-24].

At this study the effect of inoculation with three Glomus species, isolated from mine soils, has been investigated to study its impacts on the metal tolerance and accumulation abilities of hemp. Previous studies showed that Hemp, Cannabis sativa, is a fast growing, metal tolerant, and high biomass producing plant that has evolved mechanisms enabling it to cope with high heavy metal contaminated soils [25-26]. The possibilities of growing in different climates and using its biomass in non-food industries can make hemp a proper crop to recover the heavy metal contaminated soils' productivity, and, although slowly, restore them at the same time.

The objectives of this study were to investigate the influences of different levels of $\mathrm{Pb}$ and Glomus species on some chemical and biological characteristics of an artificially polluted soil and $\mathrm{Pb}$ phytoextraction by $C$. sativa.

\section{Materials and methods}

An agricultural soil (Fluventic Haploxerept) was sampled from 0 to $30 \mathrm{~cm}$ depth of a farm located at Joraghan, Hamadan, Iran. The soil was brought to the laboratory, hand-picked to remove stones, air dried, passed through a $2 \mathrm{~mm}$ sieve and mixed thoroughly. A sub-sample of the soil was taken and analysed for selected physicochemical properties (Table 1).

Table 1. Physical and chemical properties of the soil used in this experiment

\begin{tabular}{cc}
\hline Properties value & value \\
\hline Texture & Sandy loam \\
Clay & $18(\%)$ \\
Sand & $56(\%)$ \\
Silt & $26(\%)$ \\
pH & 7.7 \\
$\mathrm{CaCO}_{3}$ Equivalent & $8(\%)$ \\
$\mathrm{CEC}$ & $8\left(\mathrm{Cmolc} \cdot \mathrm{kg}^{-1}\right)$ \\
Organic carbon & $0.9(\%)$ \\
EC & $1.2\left(\mathrm{dS} \cdot \mathrm{m}^{-1}\right)$ \\
$\mathrm{P}($ Olsen $)$ & $3.2\left(\mathrm{mg} \cdot \mathrm{kg}^{-1}\right)$ \\
$\mathrm{Pb}$ (total) & $70.0\left(\mathrm{mg} \cdot \mathrm{kg}^{-1}\right)$ \\
\hline
\end{tabular}

$\mathrm{Pb}$ was added to the soil as $\mathrm{Pb}\left(\mathrm{NO}_{3}\right)_{2}$ solution for polluting of control (sampling soil had $70 \mathrm{mg} \cdot \mathrm{kg}^{-1} \mathrm{~Pb}$ before $\mathrm{Pb}$ adding), 600, 1200 and $1800 \mathrm{mg} \cdot \mathrm{kg}^{-1} \mathrm{~Pb}$ soil. Urea was supplied to equilibrate the $\mathrm{N}$ level in $\mathrm{Pb}\left(\mathrm{NO}_{3}\right)_{2}$ treated and untreated soils.

After mixing, the soils were placed in plastic cups and incubated at $25-28^{\circ} \mathrm{C}$ for 90 days. After rapid $\mathrm{Pb}$ reaction and its equilibrium in soil [27], each soil was sterilized separately with hot steam by a steam sterilization machine.

Three Glomus species including G.mosseae (Funneliformis mosseae), G.etunicatum (Claroideoglomus etunicatum) 
and G.constrictum (Septoglomus constrictum) were isolated from Zanjan $\mathrm{Zn}-\mathrm{Pb}$ mine (Zanjan Province, west of Iran), Dasht-e-Tabriz (East-Azarbayjan Province, northwest of Iran) and Ahangaran Zn-Pb mine (Hamedan Province, South west of Iran), respectively.

Fungi spores were surface sterilized by washing with $10 \%$ calcium hypochlorite. The spores were then propagated in sterilized sandy soil by establishing trap cultures using maize as host plant. These pots were sustained for about four months and during this time were irrigated three times a week, once with sterilized Hoagland solutions (with half strength of phosphorus) and the two other times with sterilized distilled water.

The AM inoculums comprised of a mixture of rhizospheric soil from trap cultures containing spores (350 spore $\cdot \mathrm{g}^{-1}$ inoculum), hyphae and mycorrhizal root fragments, as much as $70 \mathrm{~g}$ per $4 \mathrm{~kg} \cdot$ pot, were layered at $5 \mathrm{~cm}$ below the hemp seeds. The hemp seeds previously were surface sterilized by soaking in $1 \%$ sodium hypochlorite $(\mathrm{NaOCl})$ for $5 \mathrm{~min}$ and subsequently rinsed thoroughly with sterilized water. Also, for the non-inoculated treatment, a $70 \mathrm{~g}$ sterilized inoculum was added. Three replications were applied to each treatment with a total of 48 pots in the greenhouse, College of Agriculture, Bu-Ali Sina University.

At the beginning, each pot was planted with 8 seeds of hemp and then reduced to 4 plants in each pot one week after sowing. The greenhouse temperature during the growing period was 21 to $32^{\circ} \mathrm{C}$. During this period, in order to maintain soil moisture at field capacity, tap water was added twice a week to the saucer, so soil gets wet by capillary.

At the end of growth, the chlorophyll content of leaves was measured using a chlorophyll meter (Minolta Spad502) and three readings were taken of leaves of middle third of hemp shoots.

After 65 days, in flowering stage of growth of the hemp, harvest began and shoots and roots were separated. A part of the plant roots was stained with trypan-blue dye and the percentage of root mycorrhizal colonization was estimated using grid-line intersect method [28].

After plant harvesting, shoots and roots were separated, washed with distilled water, oven-dried at $70^{\circ} \mathrm{C}$ for $72 \mathrm{~h}$, weighed, powdered, and digested and extracted with $4 \mathrm{M} \mathrm{HNO}_{3}$ at $95^{\circ} \mathrm{C}[29]$ and $\mathrm{Pb}$ was measured in the filtrate. The concentration of $\mathrm{Pb}$ in the soil samples was determined according to [30]: $3 \mathrm{~g}$ soil was pre-digested with $28 \mathrm{~mL} 3: 1$ ratio of $37 \% \mathrm{HCL}: 70 \% \mathrm{HNO}_{3}$ mixture for $16 \mathrm{~h}$ at room temperature and then was digested at $130^{\circ} \mathrm{C}$ for $2 \mathrm{~h}$ in a reflux condenser. DTPA extraction of $\mathrm{Pb}$ was carried out by shaking $5 \mathrm{~g}$ of soil samples with $10 \mathrm{~mL}$ of a solution of $0.005 \mathrm{M}$ DTPA, $0.1 \mathrm{M}$ triethanolamine (TEA) and $0.01 \mathrm{M} \mathrm{CaCl}_{2}$ in an end-over-end shaker for 2 hours and then filtering the leachate [31]. The $\mathrm{Pb}$ concentration in solutions was determined by atomic absorption spectrophotometry (AAS) (Varian, spectra 220).

Lead uptake by shoots from each pot was estimated from the product of the shoot $\mathrm{Pb}$ concentration and shoot bimass. Lead translocation factor was estimated from dividing $\mathrm{Pb}$ concentration in the shoot tissue by the root $\mathrm{Pb}$ concentration [32]. Enrichment factor was estimated from dividing Pb concentration in shoot tissue $\left(\mathrm{mg} \cdot \mathrm{kg}^{-1} \mathrm{plant}\right.$ dry weight) by lead concentration in soil ( $\mathrm{mg} \cdot \mathrm{kg}^{-1}$ soil dry weight) [33].

Olsen phosphorus [34] of the soil was measured, and also phosphorus concentration of shoot and root biomass were measured in digest extracts of plant using [35] method.

This study was conducted as a factorial experiment in a completely randomized design with two factors, soil $\mathrm{Pb}$ level $\left(0,600,1200\right.$ and $\left.1800 \mathrm{mg} \cdot \mathrm{kg}^{-1}\right)$ and three fungal species (G.mosseae, G.etunicatum and G.constrictum), with three replications. Data processing and statistical analyses were performed with SAS software. Duncan's multiple range test was performed at 0.05 level of significance to compare the treatments.

\section{Results and discussion}

ANOVA of effect of $\mathrm{Pb}$ and fungus treatments on plant properties:

The ANOVA results in Table 2 show significant changes in chemical and biological properties due to plant inoculation with fungus. Also, significant changes in all properties except total colonization, arbuscule, hyphae and spore number due to soil treatment by $\mathrm{Pb}$ have been seen. Although the interaction of $\mathrm{Pb}$ pollution and fungus produced different responses. 
Table 2. ANOVA of the mean squares of chemical and biological properties

\begin{tabular}{|c|c|c|c|c|}
\hline & $\mathrm{Pb}$ & Fungus & $\mathrm{Pb} *$ Fungus & error \\
\hline Df & 3 & 3 & 9 & 32 \\
\hline Root dry W & $0.18 * * *$ & $0.21 * * *$ & $0.02 \mathrm{~ns}$ & 0.02 \\
\hline Shoot $\mathrm{Pb}$ con. & $60341.04 * * *$ & $398.80 * * *$ & $90.86^{* *}$ & 23.64 \\
\hline $\mathrm{Pb}$ uptake by shoot & $1.19^{* * *}$ & $0.11^{* * *}$ & $0.01 *$ & $0.47 \times 10^{-2}$ \\
\hline Translocation F & $0.22 * * *$ & $0.73 \times 10^{-2} *$ & $0.15 \times 10^{-1} * * *$ & $0.23 \times 10^{-2}$ \\
\hline Enrichment F & $0.10 * * *$ & $0.67 \times 10^{-3} * *$ & $0.14 \times 10^{-3} \mathrm{~ns}$ & $0.10 \times 10^{-3}$ \\
\hline Root Phosphorus con. & $10.52 * * *$ & $1.60 * * *$ & $0.03 \mathrm{~ns}$ & 0.04 \\
\hline Total Colonization & $0.21 \mathrm{~ns}$ & $39.78 * * *$ & $0.08 \mathrm{~ns}$ & 0.20 \\
\hline Arbuscule & $0.16 \mathrm{~ns}$ & $31.94 * * *$ & $0.03 \mathrm{~ns}$ & 0.16 \\
\hline Vesicle & $0.11 * * *$ & $15.82 * * *$ & $0.03 *$ & 0.01 \\
\hline hyphea & $0.20 \mathrm{~ns}$ & $29.83 * * *$ & $0.25 \mathrm{~ns}$ & 0.13 \\
\hline Spore number & $10.10 \mathrm{~ns}$ & $3468.00 * * *$ & $2.18 \mathrm{~ns}$ & 7.04 \\
\hline ChlorophyII & $112.88^{* * *}$ & $22.30 * * *$ & $6.15^{* * *}$ & 1.18 \\
\hline
\end{tabular}

Significant are noted by: $* * * p<0.001 ; * * p<0.01 ; * p<0.05 ; \mathrm{ns}, p>0.05$

$\mathrm{Pb}$ total and DTPA concentrations;

Figure 1 shows the changes in the soil concentrations of total and DTPA extractable $\mathrm{Pb}$ after addition of soluble $\mathrm{Pb}$ to the soil. It is observable that DTPA-extractable $\mathrm{Pb}$ concentration increased with increase in Pb levels, but not at the same rate as total $\mathrm{Pb}$ concentration. This may be related to decrease of DTPA extractable $\mathrm{Pb}$ due to its precipitation and immobilization in soil in 90 days of soil incubation.

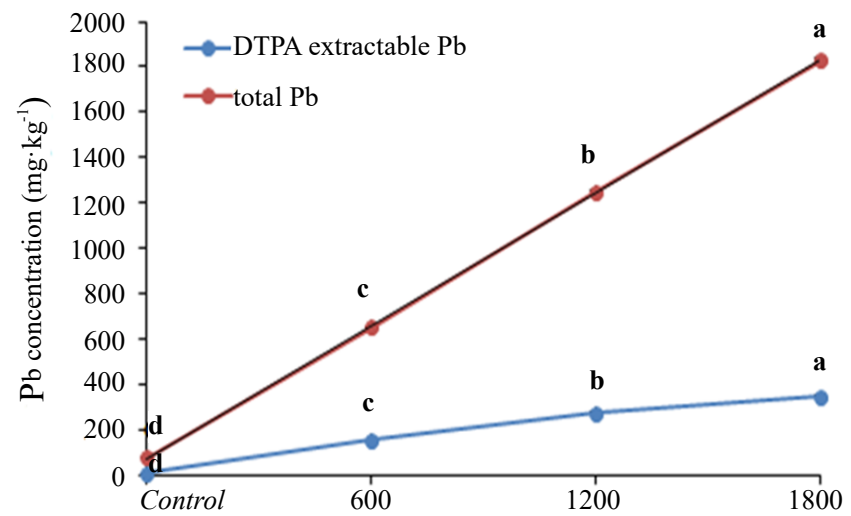

Figure 1. DTPA-extractable and total $\mathrm{Pb}$ in soils treated with different levels of $\mathrm{Pb}$

Plant growth and performance;

Shoot and root dry weights showed sharp response to soil $\mathrm{Pb}$ pollution (Table 3). Shoot mean dry weight decreased 
from $6.04 \mathrm{~g} \cdot \operatorname{pot}^{-1}$ for hemps planted in control soil to $5.74,5.18$ and $4.55 \mathrm{~g} \cdot \operatorname{pot}^{-1}$ for hemps planted in soils treated with 600,1200 and $1800 \mathrm{mg} \cdot \mathrm{kg}^{-1} \mathrm{~Pb}$ respectively. Root mean dry weight decreased from $0.82 \mathrm{~g} \cdot$ pot $^{-1}$ for hemp in control soil to $0.63,0.59$ and $0.55 \mathrm{~g} \cdot$ pot $^{-1}$ for hemps planted in 600,1200 and $1800 \mathrm{mg} \cdot \mathrm{kg}^{-1} \mathrm{~Pb}$ soil.

Table 3. Means $( \pm \mathrm{SD})$ of soil Olsen phosphorus and some plant properties

\begin{tabular}{cccccccc}
\hline $\mathrm{Pb}$ & fungus & Soil Olsen P & $\begin{array}{c}\text { Shoot DW } \\
\left(\mathrm{g} \cdot \mathrm{pot}^{-1}\right)\end{array}$ & $\begin{array}{c}\text { Root DW } \\
\left(\mathrm{g} \cdot \mathrm{pot}^{-1}\right)\end{array}$ & $\begin{array}{c}\text { Shoot } \mathrm{P} \mathrm{con} . \\
\left(\mathrm{mg} \cdot \mathrm{g}^{-1}\right)\end{array}$ & $\begin{array}{c}\text { Root P con } \\
\left(\mathrm{mg} \cdot \mathrm{g}^{-1}\right)\end{array}$ & $\begin{array}{c}\text { Chlorophyll index } \\
(\mathrm{spad})\end{array}$ \\
\hline 0 & G.mosseae & $11.52 \mathrm{ab}(0.26)$ & $5.86 \mathrm{bcd}(0.45)$ & $0.79 \mathrm{~b}(0.21)$ & $6.44 \mathrm{de}(0.15)$ & $5.37 \mathrm{abc}(0.19)$ & $36.00 \mathrm{~b}(0.80)$ \\
& G.etunicatum & $11.55 \mathrm{ab}(0.20)$ & $6.93 \mathrm{a}(0.31)$ & $1.12 \mathrm{a}(0.06)$ & $8.00 \mathrm{a}(0.45)$ & $5.39 \mathrm{ab}(0.29)$ & $38.17 \mathrm{a}(1.60)$ \\
& G.constrictum & $11.87 \mathrm{a}(0.15)$ & $6.26 \mathrm{ab}(0.39)$ & $0.74 \mathrm{bc}(0.32)$ & $7.60 \mathrm{ab}(0.41)$ & $5.56 \mathrm{a}(0.32)$ & $38.27 \mathrm{a}(1.22)$ \\
& Non-inoculated & $11.55 \mathrm{ab}(0.14)$ & $5.13 \mathrm{def}(0.18)$ & $0.62 \mathrm{bcde}(0.09)$ & $6.03 \mathrm{ef}(0.25)$ & $4.75 \mathrm{~d}(0.16)$ & $34.53 \mathrm{bc}(1.51)$ \\
600 & G.mosseae & $11.25 \mathrm{bc}(0.19)$ & $5.48 \mathrm{bcde}(0.46)$ & $0.46 \mathrm{de}(0.09)$ & $6.74 \mathrm{~cd}(0.38)$ & $5.00 \mathrm{~cd}(0.21)$ & $34.23 \mathrm{bcd}(1.37)$ \\
& G.etunicatum & $11.28 \mathrm{bc}(0.18)$ & $6.19 \mathrm{abc}(0.34)$ & $0.78 \mathrm{~b}(0.09)$ & $6.46 \mathrm{de}(0.68)$ & $5.12 \mathrm{bcd}(0.20)$ & $32.37 \mathrm{~d}(0.55)$ \\
& G.constrictum & $11.70 \mathrm{a}(0.25)$ & $6.12 \mathrm{abc}(0.83)$ & $0.73 \mathrm{bc}(0.10)$ & $7.10 \mathrm{bc}(0.36)$ & $5.07 \mathrm{bcd}(0.22)$ & $33.70 \mathrm{~cd}(1.15)$ \\
& Non-inoculated & $11.23 \mathrm{bc}(0.15)$ & $5.16 \mathrm{def}(0.38)$ & $0.55 \mathrm{bcde}(0.06)$ & $5.45 \mathrm{f}(0.58)$ & $4.28 \mathrm{e}(0.17)$ & $33.00 \mathrm{~cd}(1.00)$ \\
1200 & G.mosseae & $10.98 \mathrm{~cd}(0.16)$ & $4.81 \mathrm{ef}(0.47)$ & $0.50 \mathrm{cde}(0.12)$ & $5.51 \mathrm{f}(0.13)$ & $4.36 \mathrm{e}(0.20)$ & $29.13 \mathrm{ef}(1.33)$ \\
& G.etunicatum & $11.17 \mathrm{bc}(0.15)$ & $6.28 \mathrm{ab}(0.31)$ & $0.70 \mathrm{bcd}(0.10)$ & $5.61 \mathrm{f}(0.22)$ & $4.12 \mathrm{e}(0.29)$ & $32.37 \mathrm{~d}(0.61)$ \\
& G.constrictum & $11.30 \mathrm{bc}(0.25)$ & $4.90 \mathrm{ef}(0.72)$ & $0.68 \mathrm{bcd}(0.13)$ & $5.54 \mathrm{f}(0.26)$ & $4.14 \mathrm{e}(0.17)$ & $32.47 \mathrm{~d}(0.93)$ \\
& Non-inoculated & $10.93 \mathrm{~cd}(0.13)$ & $4.72 \mathrm{ef}(0.33)$ & $0.46 \mathrm{de}(0.04)$ & $4.69 \mathrm{~g}(0.23)$ & $3.50 \mathrm{f}(0.15)$ & $27.63 \mathrm{f}(1.26)$ \\
1800 & G.mosseae & $10.70 \mathrm{de}(0.34)$ & $4.51 \mathrm{fg}(0.61)$ & $0.51 \mathrm{cde}(0.09)$ & $4.60 \mathrm{~g}(0.37)$ & $3.48 \mathrm{f}(0.15)$ & $29.03 \mathrm{ef}(1.15)$ \\
& G.etunicatum & $10.71 \mathrm{de}(0.31)$ & $5.36 \mathrm{cdef}(0.62)$ & $0.63 \mathrm{bcde}(0.12)$ & $4.32 \mathrm{~g}(0.22)$ & $3.30 \mathrm{f}(0.17)$ & $33.10 \mathrm{~cd}(0.36)$ \\
& G.constrictum & $11.02 \mathrm{~cd}(0.22)$ & $4.55 \mathrm{fg}(0.36)$ & $0.62 \mathrm{bcde}(0.09)$ & $4.36 \mathrm{~g}(0.21)$ & $3.24 \mathrm{f}(0.20)$ & $29.77 \mathrm{e}(0.95)$ \\
& Non-inoculated & $10.45 \mathrm{e}(0.21)$ & $3.78 \mathrm{~g}(0.34)$ & $0.42 \mathrm{e}(0.08)$ & $3.15 \mathrm{~h}(0.14)$ & $2.61 \mathrm{~g}(0.16)$ & $28.93 \mathrm{ef}(0.70)$ \\
\hline
\end{tabular}

Means within each column with the same letter are not significantly different at the $5 \%$ level

Hemp growth was greatly influenced by AM inoculation. Shoot and root biomasses compared with those for the non-inoculated hemp significantly were higher. The highest mean dry weight of shoot $\left(6.19 \mathrm{~g} \cdot \mathrm{pot}^{-1}\right)$ was observed in hemp inoculated with G.etunicatum, and followed by G.constrictum inoculated (5.46 g.pot $\left.{ }^{-1}\right)$, G.mosseae inoculated (5.17 $\left.\mathrm{g} \cdot \operatorname{pot}^{-1}\right)$ and the non-inoculated $\left(4.70 \mathrm{~g} \cdot\right.$ pot $\left.^{-1}\right)$ hemps. Root dry weights decreased to $0.81,0.70,0.57$ and $0.51 \mathrm{~g} \cdot \operatorname{pot}^{-1}$ for G.etunicatum-, G.constrictum-, G.mosseae-inoculated and the non-inoculated hemps, respectively. Other researchers reported the decrease in root biomass with increase in $\mathrm{Pb}$ contamination and also the increase of root and shoot dry weights by application biofertilizer of Glomus mosseae [36]. The decrease in plant growth due to heavy metal stress could be because of damage of root cell walls and decrease in the absorption of nutrients [37]. Furthermore there are some physical and chemical reactions between heavy metals and soil components (for example organic matter) that lead to reduced soil fertility [38].

The chlorophyll content of leaves decreased with the increase in $\mathrm{Pb}$ level in soil. Other researchers reported a decrease in chlorophyll content of plants grown in soils with contamination of heavy metals, especially with $\mathrm{Cu}$ and $\mathrm{Pb}$ pollutions [39-42]. This could be because of competition of $\mathrm{Pb}$ with nutrient elements, change in the permeability of cell membranes, and replacement of $\mathrm{Mg}$ with $\mathrm{Pb}$ in chlorophyll structure that resulted in reduce in synthesis of photosynthetic pigments [43].

The inoculation of hemp with AM fungi increased the chlorophyll content of plant. The effect of fungi on chlorophyll content was in the following order: G.etunicatum $=$ G.constrictum $>$ G.mosseae $>$ non-inoculated. The highest chlorophyll content (38.27 spad) was observed in the hemp inoculated with G.constrictum planted in the control soil and the lowest contents were observed in hemps inoculated with G.mosseae and non-inoculated hemps planted in 1200 and $1800 \mathrm{mg} \cdot \mathrm{kg}^{-1} \mathrm{~Pb}$ polluted soils. This could be related to the role of mycorrhizal fungi in providing phosphorus 
as an energy source during photosynthesis [44].

On the average, phosphorus concentration in shoot tissues of hemp decreased with the increase in Pb level in soil. The highest phosphorus concentration in shoots $\left(8.00 \mathrm{mg} \cdot \mathrm{g}^{-1}\right)$ measured in hemp inoculated with G.etunicatum planted in control soil and the lowest $\left(3.15 \mathrm{mg} \cdot \mathrm{g}^{-1}\right)$ was observed in shoots of non-inoculated hemp planted in soil with 1800 $\mathrm{mg} \cdot \mathrm{kg}^{-1} \mathrm{~Pb}$. The phosphorus concentration of roots also decreased with the increase in $\mathrm{Pb}$ level in soil and changed from $5.27 \mathrm{mg} \cdot \mathrm{g}^{-1}$ for control to $4.87,4.03$ and $3.16 \mathrm{mg} \cdot \mathrm{g}^{-1}$ for 600,1200 and $1800 \mathrm{mg} \cdot \mathrm{kg}^{-1} \mathrm{~Pb}$ respectively. [45] illustrated that great amounts of $\mathrm{Pb}$ in soil can cause phosphorus to precipitate, so its absorption by plants will be reduced.

Inoculation of hemp roots with AM fungus, increased the phosphorus concentration in shoot and root tissues. Fungus treatments affect the phosphorus concentration in shoot tissues of hemp in this manner G.constrictum > G.etunicatum > G.mosseae > non-inoculated. This manner for phosphorus concentration in root tissues was G.mosseae $=$ G.constrictum $=$ G.etunicatum $>$ non-inoculated. Mycorrhizal fungi can directly uptake phosphorus through its hyphae and transfer it to plant and furthermore it may contribute to decreased soil $\mathrm{pH}$ that resulted in solubilizing of insoluble phosphates in the soil and subsequently more uptake of phosphorus by plant roots [46].

AM fungal colonization status;

Spore numbers in soil treated with G.constrictum is higher than other fungi treatments. A few spore numbers counted in the non-inoculated pots is related to spores that retained their shape during the soil sterilization, and also some spores are from fungus pollution during the growth period. It is in accordance with the microscopic observation of the root sections. Low root colonization percentage for the non-inoculated roots shows fungi pollution of hemps in these pots.

No significant difference in spore numbers was found as a result of $\mathrm{Pb}$ pollution (Table 2). In other studies by planting Zea mays in contaminated soils with heavy metals, no changes were reported in mycorrhizal spore numbers due to increase of heavy metals concentration [47].

Figure 2 shows mycorrhizal vesicles and hyphae in hemp root. The percentage of root colonization of hemps inoculated with G.mosseae and G.constrictum increased with increasing Pb level in soil from 0 to $1200 \mathrm{mg} \cdot \mathrm{kg}^{-1}$ and then it decreased (not significantly) at $1800 \mathrm{mg} \cdot \mathrm{kg}^{-1} \mathrm{~Pb}$ pollution.

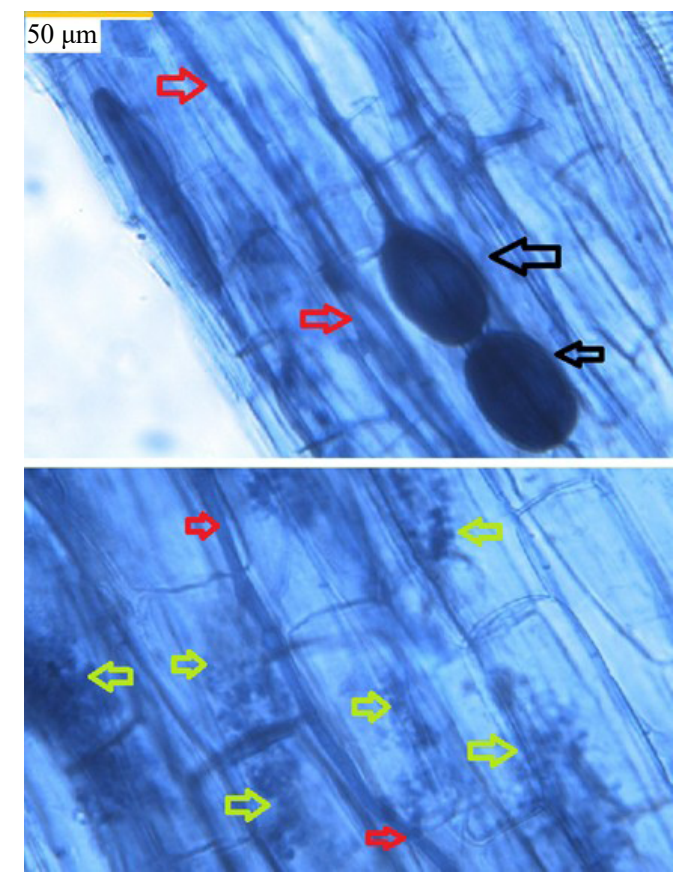

Figure 2. Stained roots of hemp showing fungal organs in the cortex. Black, green, and red arrows showed mycorrhizal vesicles, arbuscules, and hyphae respectively 
But the percentage of root colonization of G.etunicatum inoculated hemps, decreased (not significantly) with increasing $\mathrm{Pb}$ level in soil (Table 4).

Although some researchers reported a decrease in root colonization by mycorrhizal fungi with increasing heavy metal pollution [48-50], others reported the reverse results same as our observation [51-52]. [14] concluded that fungus and plant species as micro and macrosymbionts, heavy metal concentration, and soil properties are all important, and have specific effects on the root colonization percentage.

Table 4. Means (std division) of root mycorrhizal colonization and spore numbers of soil

\begin{tabular}{|c|c|c|c|c|c|c|}
\hline $\mathrm{Pb}$ & fungus & arbuscules (\%) & vesicles (\%) & hyphae (\%) & Colonization (\%) & Spore number $\left(\right.$ num $\left.\cdot \mathrm{g}^{-1}\right)$ \\
\hline \multirow[t]{4}{*}{0} & G.mosseae & $22.84 \mathrm{~d}(3.35)$ & $2.20 \mathrm{c}(0.30)$ & $6.05(2.08) \mathrm{de}$ & $29.58 \mathrm{e}(6.19)$ & $45.15 \mathrm{c}(2.72)$ \\
\hline & G.etunicatum & $23.68 \mathrm{~cd}(4.56)$ & $8.80 \mathrm{a}(0.30)$ & $18.98 \mathrm{a}(0.50)$ & $48.87 \mathrm{bc}(4.84)$ & $46.59 \mathrm{bc}(3.41)$ \\
\hline & G.constrictum & 29.73abc (3.65) & $1.93 \mathrm{~cd}(0.15)$ & $18.70 \mathrm{a}(3.93)$ & $48.43 \mathrm{bc}(0.58)$ & $49.22 \mathrm{abc}(2.81)$ \\
\hline & Non-inoculated & $0.56 \mathrm{e}(0.96)$ & $0.00 f(0.00)$ & $0.00 \mathrm{e}(0.00)$ & $0.56 \mathrm{f}(0.96)$ & $14.13 \mathrm{~d}(4.49)$ \\
\hline \multirow[t]{4}{*}{600} & G.mosseae & 29.03abcd (3.51) & 1.63 de $(0.50)$ & $11.93 \mathrm{bcd}(3.10)$ & $41.88 \mathrm{~d}(2.20)$ & $44.43 \mathrm{c}(2.75)$ \\
\hline & G.etunicatum & $30.03 \mathrm{abc}(2.90)$ & $8.14 b(0.25)$ & $14.55 \mathrm{abc}(5.91)$ & 46.40bcd (3.14) & $47.07 \mathrm{abc}(4.35)$ \\
\hline & G.constrictum & $31.20 \mathrm{ab}(2.55)$ & $1.57 \mathrm{de}(0.38)$ & $17.85 \mathrm{abc}(4.20)$ & $49.95 \mathrm{~b}(3.38)$ & 49.10abc (3.06) \\
\hline & Non-inoculated & $1.31 \mathrm{e}(1.14)$ & $0.00 \mathrm{f}(0.00)$ & $0.71 \mathrm{e}(1.23)$ & $2.02 \mathrm{f}(2.14)$ & $14.61 \mathrm{~d}(2.90)$ \\
\hline \multirow[t]{4}{*}{1200} & G.mosseae & $27.33 \mathrm{bcd}(1.80)$ & $1.23 \mathrm{e}(0.25)$ & $18.30 \mathrm{ab}(2.07)$ & $46.03 \mathrm{bcd}(3.03)$ & 47.43abc (1.07) \\
\hline & G.etunicatum & $27.33 \mathrm{bcd}(2.08)$ & $7.92 b(0.18)$ & $13.70 \mathrm{abc}(4.72)$ & 46.86bcd (2.85) & $48.27 \mathrm{abc}(0.90)$ \\
\hline & G.constrictum & $35.06 \mathrm{a}(5.39)$ & 1.63 de $(0.42)$ & $19.17 \mathrm{a}(7.68)$ & $55.69 \mathrm{a}(3.09)$ & $51.98 \mathrm{a}(0.91)$ \\
\hline & Non-inoculated & $1.06 \mathrm{e}(0.92)$ & $0.00 f(0.00)$ & $0.52 \mathrm{e}(0.90)$ & $1.58 \mathrm{f}(1.57)$ & $14.01 \mathrm{~d}(3.43)$ \\
\hline \multirow[t]{4}{*}{1800} & G.mosseae & 29.24abcd (4.16) & $1.27 \mathrm{e}(0.15)$ & $11.58 \mathrm{~cd}(3.61)$ & $42.03 \mathrm{~d}(2.92)$ & $47.67 \mathrm{abc}(0.55)$ \\
\hline & G.etunicatum & $22.92 \mathrm{~d}(3.89)$ & $8.08 \mathrm{~b}(0.39)$ & $13.56 \mathrm{abc}(2.42)$ & $43.32 \mathrm{~cd}(2.90)$ & $48.15 \mathrm{abc}(0.36)$ \\
\hline & G.constrictum & $31.27 \mathrm{ab}(6.82)$ & $1.33 \mathrm{e}(0.15)$ & $18.74 \mathrm{a}(2.81)$ & $50.98 \mathrm{ab}(4.97)$ & $51.38 \mathrm{ab}(0.72)$ \\
\hline & Non-inoculated & $1.10 \mathrm{e}(0.97)$ & $0.00 f(0.00)$ & $0.00 \mathrm{e}(0.00)$ & $1.10 \mathrm{f}(0.97)$ & $14.13 \mathrm{~d}(2.39)$ \\
\hline
\end{tabular}

Means within each column with the same letter are not significantly different at the $5 \%$ level

The highest percentage of root AM colonization (55.69\%) was observed in hemp inoculated with G.constrictum planted in $1200 \mathrm{mg} \cdot \mathrm{kg}^{-1} \mathrm{~Pb}$ polluted soil and the lowest values $(0.56$ to $2.02 \%)$ were observed in the non-inoculated hemps. This low root colonization of the non-inoculated hemps may be due to the imperfect sterilization of soil and/ or infection of soil during the growth period of hemps by irrigation with tap water and aeration with unsterile air of the greenhouse.

Arbuscules percentage in plant roots was the lowest one (19.20\%) in control soil and it increased with increasing the levels of $\mathrm{Pb}$ in soil. It was $22.89 \%$ and $22.69 \%$ in soil treated with 600 and $1200 \mathrm{mg} \cdot \mathrm{kg}^{-1} \mathrm{~Pb}$ respectively. Arbuscules percentage in plant roots decreased in soil treated with $1800 \mathrm{mg} \cdot \mathrm{kg}^{-1} \mathrm{~Pb}(21.13 \%)$. Arbuscules percentage in all of the inoculated plants was higher than that in the non-inoculated plants. Plant inoculated with G.constrictum had the highest arbuscules percentage in roots $(31.81 \%)$.

Vesicles percentage in roots of hemp was lower than the arbuscules and hyphae percentage may be due to the harvesting time. It was at the flowering stage of plants. Vesicles percentage decreased with increase in $\mathrm{Pb}$ level in soil from control (3.23\%) to $600(2.83 \%), 1200(2.70 \%)$ and $1800 \mathrm{mg} \cdot \mathrm{kg}^{-1} \mathrm{~Pb}$ level $(2.67 \%)$. Vesicles percentage in roots of plants inoculated with G.etunicatum $(8.23 \%)$ was higher than that in roots of plants inoculated with G.constrictum $(1.62 \%)$ and G.mosseae (1.58\%). Vesicles percentage in roots of non-inoculated plants was $0.00 \%$.

In contrast to arbuscules and vesicles percentages, hyphae percentage in roots of hemp decreased, though not significantly, with increasing of $\mathrm{Pb}$ level in soil. It was significantly higher in inoculated plants compared with that 
of non-inoculated plants. Plants inoculated with G.constrictum had the highest hyphae percentage (18.62\%). Plants inoculated with G.etunicatum (15.20\%) and G.mosseae (11.97\%), and non-inoculated plants (0.31\%) had lower hyphae percentage.

[36] and [54] reported higher root colonization due to the increase of heavy metals concentration in soil.

Plant $\mathrm{Pb}$ uptake and translocation;

The concentration of $\mathrm{Pb}$ increased in both the root and shoot tissues of hemps with increasing the $\mathrm{Pb}$ levels in soil.

Same as other reports it was higher in the root tissues of hemps compared with that of shoot tissues (Table 5).

Shoot $\mathrm{Pb}$ concentrations decreased from $195.25 \mathrm{mg} \cdot \mathrm{kg}^{-1}$ for hemp planted in the soil treated with $1800 \mathrm{mg} \cdot \mathrm{kg}^{-1} \mathrm{~Pb}$ to $152.50,106.81$ and $29.47 \mathrm{mg} \cdot \mathrm{kg}^{-1}$ for hemps planted in the soils treated with $1200,600,0 \mathrm{mg} \cdot \mathrm{kg}^{-1} \mathrm{~Pb}$, respectively. Similarly root $\mathrm{Pb}$ concentrations decreased from $437.55 \mathrm{mg} \cdot \mathrm{kg}^{-1}$ for hemp planted in the soil treated with 1800 $\mathrm{mg} \cdot \mathrm{kg}^{-1} \mathrm{~Pb}$ to $288.49,167.98$ and $39.86 \mathrm{mg} \cdot \mathrm{kg}^{-1}$ for hemps planted in the soils treated with 1200,600 and $0 \mathrm{mg} \cdot \mathrm{kg}^{-1}$ $\mathrm{Pb}$, respectively. The highest $\mathrm{Pb}$ concentration in shoots $\left(208.33 \mathrm{mg} \cdot \mathrm{kg}^{-1}\right)$ was observed in the hemp inoculated with G.constrictum in soil treated with $1800 \mathrm{mg} \cdot \mathrm{kg}^{-1} \mathrm{~Pb}$ (Table 5). Hemps planted in control soil (the untreated soil with $\mathrm{Pb}$ ) had the lowest shoot $\mathrm{Pb}$ concentration.

Table 5. Means (std division) of $\mathrm{Pb}$ absorb factors by the hemp

\begin{tabular}{|c|c|c|c|c|c|c|}
\hline $\mathrm{Pb}$ & fungus & $\begin{array}{c}\text { Shoot } \mathrm{Pb} \text { con. } \\
\left(\mathrm{mg} \cdot \mathrm{kg}^{-1}\right)\end{array}$ & $\begin{array}{l}\text { Root } \mathrm{Pb} \text { con. } \\
\left(\mathrm{mg} \cdot \mathrm{kg}^{-1}\right)\end{array}$ & $\begin{array}{c}\mathrm{Pb} \text { uptake by shoot } \\
\left(\mathrm{mg} \cdot \mathrm{pot}^{-1}\right)\end{array}$ & Translocation F & Enrichment $\mathrm{F}$ \\
\hline \multirow[t]{4}{*}{0} & G.mosseae & $28.18 \mathrm{~g}(0.84)$ & $37.72 \mathrm{gh}(4.72)$ & $0.17 \mathrm{~g}(0.02)$ & $0.75 b(0.08)$ & $0.30 \mathrm{~b}(0.01)$ \\
\hline & G.etunicatum & $30.64 \mathrm{~g}(3.07)$ & $44.11 \mathrm{~g}(0.43)$ & $0.22 \mathrm{~g}(0.03)$ & $0.69 \mathrm{bc}(0.06)$ & $0.32 \mathrm{a}(0.03)$ \\
\hline & G.constrictum & $30.24 \mathrm{~g}(1.04)$ & $46.53 \mathrm{~g}(2.10)$ & $0.19 \mathrm{~g}(0.02)$ & $0.65 \mathrm{~cd}(0.05)$ & $0.32 \mathrm{ab}(0.01)$ \\
\hline & Non-inoculated & $28.81 \mathrm{~g}(0.71)$ & 31.08h (3.44) & $0.15 \mathrm{~g}(0.00)$ & $0.93 \mathrm{a}(0.12)$ & $0.30 \mathrm{~b}(0.01)$ \\
\hline \multirow[t]{4}{*}{600} & G.mosseae & $111.96 \mathrm{e}(2.90)$ & $166.34 \mathrm{ef}(7.97)$ & $0.61 \mathrm{e}(0.04)$ & $0.67 \mathrm{bcd}(0.05)$ & $0.17 \mathrm{c}(0.01)$ \\
\hline & G.etunicatum & $112.55 \mathrm{e}(3.24)$ & $177.16 \mathrm{e}(10.91)$ & $0.70 \mathrm{de}(0.04)$ & $0.64 \mathrm{~cd}(0.03)$ & $0.18 \mathrm{c}(0.01)$ \\
\hline & G.constrictum & $107.84 \mathrm{e}(1.48)$ & $169.59 \mathrm{ef}(12.73)$ & 0.66 de $(0.10)$ & $0.64 \mathrm{~cd}(0.05)$ & $0.17 \mathrm{c}(0.01)$ \\
\hline & Non-inoculated & $94.90 f(3.24)$ & $158.82 \mathrm{f}(3.36)$ & $0.49 f(0.05)$ & $0.60 \operatorname{de}(0.03)$ & $0.15 \mathrm{~d}(0.01)$ \\
\hline \multirow[t]{4}{*}{1200} & G.mosseae & $152.82 \mathrm{~d}(4.64)$ & $294.17 \mathrm{c}(7.87)$ & $0.74 \mathrm{de}(0.09)$ & $0.52 \operatorname{efgh}(0.03)$ & $0.12 \mathrm{e}(0.01)$ \\
\hline & G.etunicatum & $155.39 \mathrm{~d}(5.38)$ & $293.49 \mathrm{c}(5.38)$ & $0.98 \mathrm{ab}(0.08)$ & $0.53 \mathrm{efg}(0.03)$ & $0.12 \mathrm{e}(0.01)$ \\
\hline & G.constrictum & $154.87 \mathrm{~d}(1.93)$ & $296.55 \mathrm{c}(6.17)$ & $0.76 \mathrm{~cd}(0.11)$ & $0.52 \operatorname{efgh}(0.01)$ & $0.12 \mathrm{e}(0.00)$ \\
\hline & Non-inoculated & $146.92 \mathrm{~d}(4.62)$ & $269.75 d(7.37)$ & $0.69 \mathrm{de}(0.07)$ & $0.55 \mathrm{ef}(0.03)$ & $0.12 \mathrm{e}(0.01)$ \\
\hline \multirow[t]{4}{*}{1800} & G.mosseae & $192.67 b(9.71)$ & $438.45 \mathrm{a}(6.83)$ & $0.87 \mathrm{bc}(0.11)$ & $0.44 \mathrm{hi}(0.02)$ & $0.11 \mathrm{ef}(0.01)$ \\
\hline & G.etunicatum & $199.67 b(5.69)$ & $445.53 \mathrm{a}(4.22)$ & $1.07 \mathrm{a}(0.07)$ & $0.45 \operatorname{ghi}(0.02)$ & $0.11 \mathrm{ef}(0.00)$ \\
\hline & G.constrictum & $208.33 \mathrm{a}(8.62)$ & $441.58 \mathrm{a}(3.68)$ & $0.95 \mathrm{ab}(0.04)$ & 0.47 fghi $(0.02)$ & $0.11 \mathrm{ef}(0.01)$ \\
\hline & Non-inoculated & $108.33 c(7.64)$ & $424.64 b(4.00)$ & $0.69 \mathrm{de}(0.09)$ & $0.42 \mathrm{i}(0.02)$ & $0.10 \mathrm{f}(0.01)$ \\
\hline
\end{tabular}

Means within each column with the same letter are not significantly different at the $5 \%$ level

Shoot $\mathrm{Pb}$ concentrations were significantly higher in the inoculated hemps with AM fungi compared with that of the non-inoculated hemp (112.74 mg $\left.\mathrm{kg}^{-1}\right)$. Shoot $\mathrm{Pb}$ concentrations were 125.32, 124.56 and $121.41 \mathrm{mg} \cdot \mathrm{kg}^{-1}$ in hemps inoculated with G.constrictum, G.etunicatum and G.mosseae respectively.

The lowest $\mathrm{Pb}$ concentration in root tissues $\left(221.07 \mathrm{mg} \cdot \mathrm{kg}^{-1}\right)$ was measured in non-inoculated hemps. Among inoculated hemps, G.etunicatum inoculated hemp showed significantly more $\mathrm{Pb}$ concentration in root tissues and then after, were the hemps inoculated with G.constrictum and G.mosseae, respectively. In fungal treatments, root Pb concentrations were $240.07,238.56$ and $234.17 \mathrm{mg} \cdot \mathrm{kg}^{-1}$ in hemps inoculated with G.etunicatum, G.constrictum and G.mosseae respectively.

Other studies [50] have reported that at high $\mathrm{Pb}$ concentration $(0.1 \mathrm{mM})$, inoculation with G.intraradices 
significantly increased the concentration of $\mathrm{Pb}$ in the shoot of $\mathrm{Z}$. mays but no changes in root $\mathrm{Pb}$ concentration was observed. They also reported converted results about Agrostis, in low $\mathrm{Pb}$ concentration $(0.01 \mathrm{mM})$, that mycorrhizal inoculation caused its root $\mathrm{Pb}$ concentration to increase but its shoot $\mathrm{Pb}$ concentration did not change.

A study [14] on Z. mays showed higher $\mathrm{Cu}$ concentration in shoot tissues of plant inoculated with Acaulospora laevis, Glomus caledonium and Glomus manihotis compared with non-inoculated plant.

In this study, $\mathrm{Pb}$ uptake in aerial parts of hemp was calculated. This is an important factor should be study in heavy metal phytoextraction. It was higher than the critical limit (30 mg $\cdot \mathrm{kg}^{-1} \mathrm{~Pb}$ plant dry weight) in shoot and root tissues of hemps planted in $\mathrm{Pb}$ polluted soils $\left(600,1200\right.$ and $\left.1800 \mathrm{mg} \cdot \mathrm{kg}^{-1} \mathrm{~Pb}\right)$. These findings are in agreement with those of [53], that found the uptake of heavy metals in plants close to a mine in China was significantly high (upper than the critical limit) compared with that of plants far from the mine.

Translocation factors (TF) of heavy metals is an index that can be used to evaluate the capacity of plants to translocate heavy metals from roots to shoots. TF, the ratio of $\mathrm{Pb}$ concentration in plant shoots to plant roots, was $<1$ and decreased with increase in $\mathrm{Pb}$ level in soil. On average, TF was the highest one in the non-inoculated hemp and closely followed by the hemps inoculated with G.mosseae, G.etunicatum and G.constrictum, respectively. Although the $\mathrm{Pb}$ concentration in root and shoots tissues of hemps increased by AM fungi but the increase of $\mathrm{Pb}$ concentration in root of hemps was higher. High TFs ( $>1)$ maybe due to the efficiency of the transport system of plant [55]. However in many studies the TF of $\mathrm{Pb}$ by various plant species in soils with different properties was lower than 1 due to it low mobility in plant root and shoots tissues [32].

Enrichment factors (EF) can be used to evaluate the ability of plants to accumulate heavy metals in aerial parts. It is calculated as the ratio of the $\mathrm{Pb}$ concentration in shoot tissues to the $\mathrm{Pb}$ concentration in soil. It decreased from 0.31 for control to $0.17,0.12$ and 0.11 for 600,1200 and $1800 \mathrm{mg} \cdot \mathrm{kg}^{-1} \mathrm{~Pb}$ treatments, respectively. Mean EF of all inoculated hemps (0.18) was significantly greater than non-inoculated hemp (0.17). This shows the increase of uptake of $\mathrm{Pb}$ by hemp inoculation with AM fungi.

$\mathrm{EF}$ is an important index to evaluate a plant's ability to absorb metals and to show the mobility of metals from soil solution to shoot tissues of plant [56]. Plants with high ability to both absorb the metal from soil (EF $>1)$ and translocate it from root to shoot tissues (TF $>1$ ), are superior for phytoremediation [32, 57]; although some researchers illustrated that some plants with $\mathrm{EF}<1$ are also accumulators for heavy metals [58].

In this study, both TF and EF decreased with increasing $\mathrm{Pb}$ level in soil. This agreed with the findings of [59], who substantiated that EF correlated to bioavailability and concentration of heavy metals in the soil.

Total uptake of $\mathrm{Pb}$ by plants increased with the increase in $\mathrm{Pb}$ level in soil. The highest value $\left(1.07 \mathrm{mg} \cdot \mathrm{pot}^{-1}\right)$ observed in the hemp inoculated with G.etunicatum planted in soil treated with $1800 \mathrm{mg} \cdot \mathrm{kg}^{-1} \mathrm{~Pb}$ and the lowest value $\left(0.15 \mathrm{mg} \cdot \mathrm{pot}^{-1}\right)$ was observed in the non-inoculated hemp in the control soil. On average, $\mathrm{Pb}$ uptake by hemp in the AM fungi treatments followed this order: G.etunicatum $>$ G.constrictum $=$ G.mosseae $>$ non-inoculated.

[36] reported that the inoculation of Vetiver grass with G.mosseae increased the uptake of $\mathrm{Pb}$ and also increased its translocation from root to shoot.

Total $\mathrm{Pb}$ uptake into the shoots of hemp had very minute values, so very little amount of soil $\mathrm{Pb}$ could be removed by harvesting the shoots at each year. Previous researchers have certified that although at least five years is required for soil remediation, longer time is usually necessary for soil clean-up [60-61].

Uptake of heavy metals by plants does not relate to the total content of heavy metals in soil as a linear equation. It is mainly depends on bioavailability of heavy metals in soils. The active fraction comprises a small amount of heavy metals in calcareous and clay soils. The precipitation and immobilization are two important reactions in soils that can cause the active fractions of heavy metals to decrease, so they can limit the ability of plants to absorb and accumulate these fractions [32].

The result of this study shows that hemp is a tolerant plant that has grown in soils with high concentrations of $\mathrm{Pb}$ (1200 and $1800 \mathrm{mg} \cdot \mathrm{kg}^{-1}$ of soil) and somewhat translocates $\mathrm{Pb}$ from roots to shoot. [39] reported hemp as nonhyperaccumulator but tolerant to $\mathrm{Cd}, \mathrm{Ni}$ and $\mathrm{Cr}$.

Figure 3 shows simple linear regressions between soil Pb extracts (DTPA and total extracts) and different phytoremediation indices. 

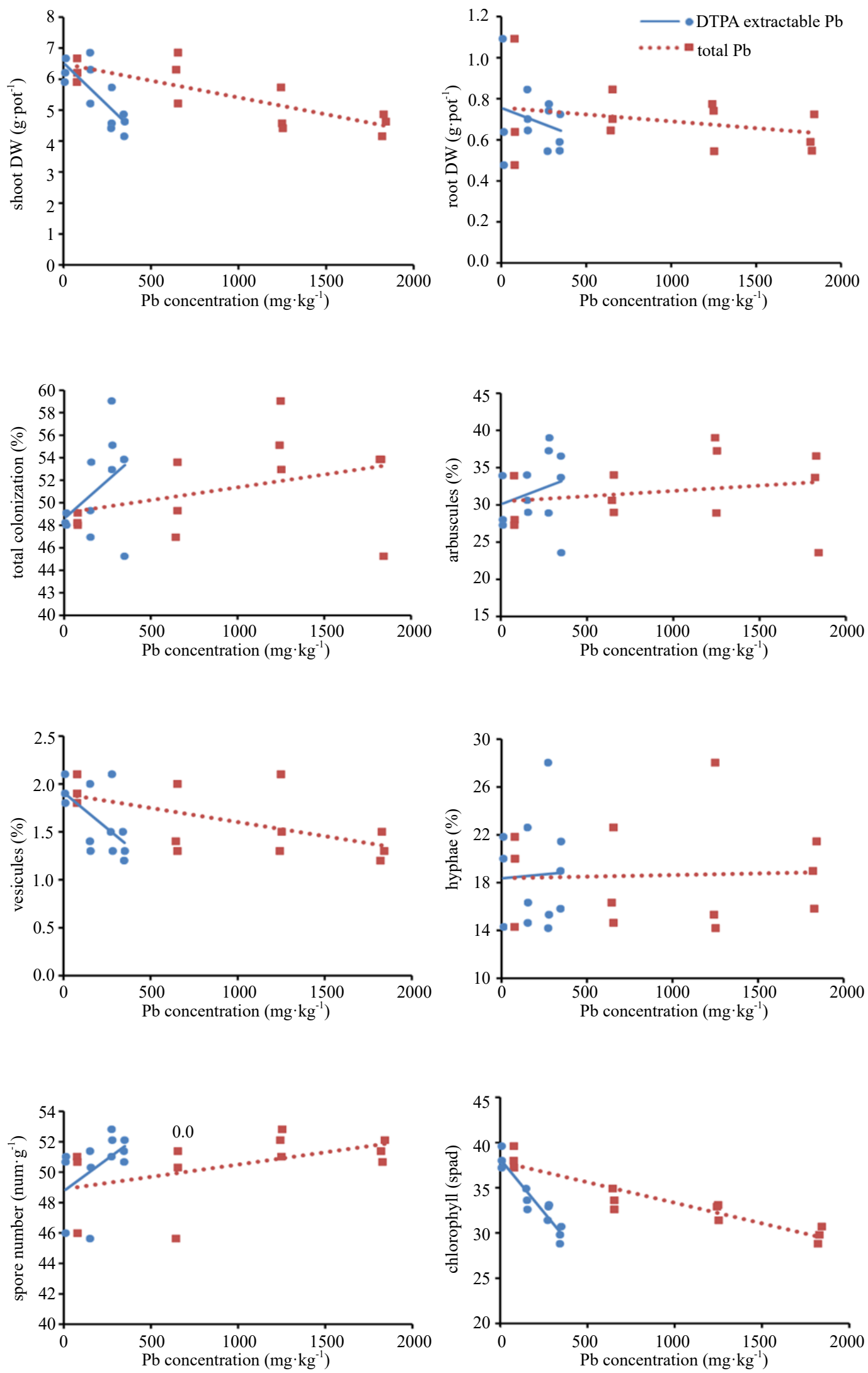

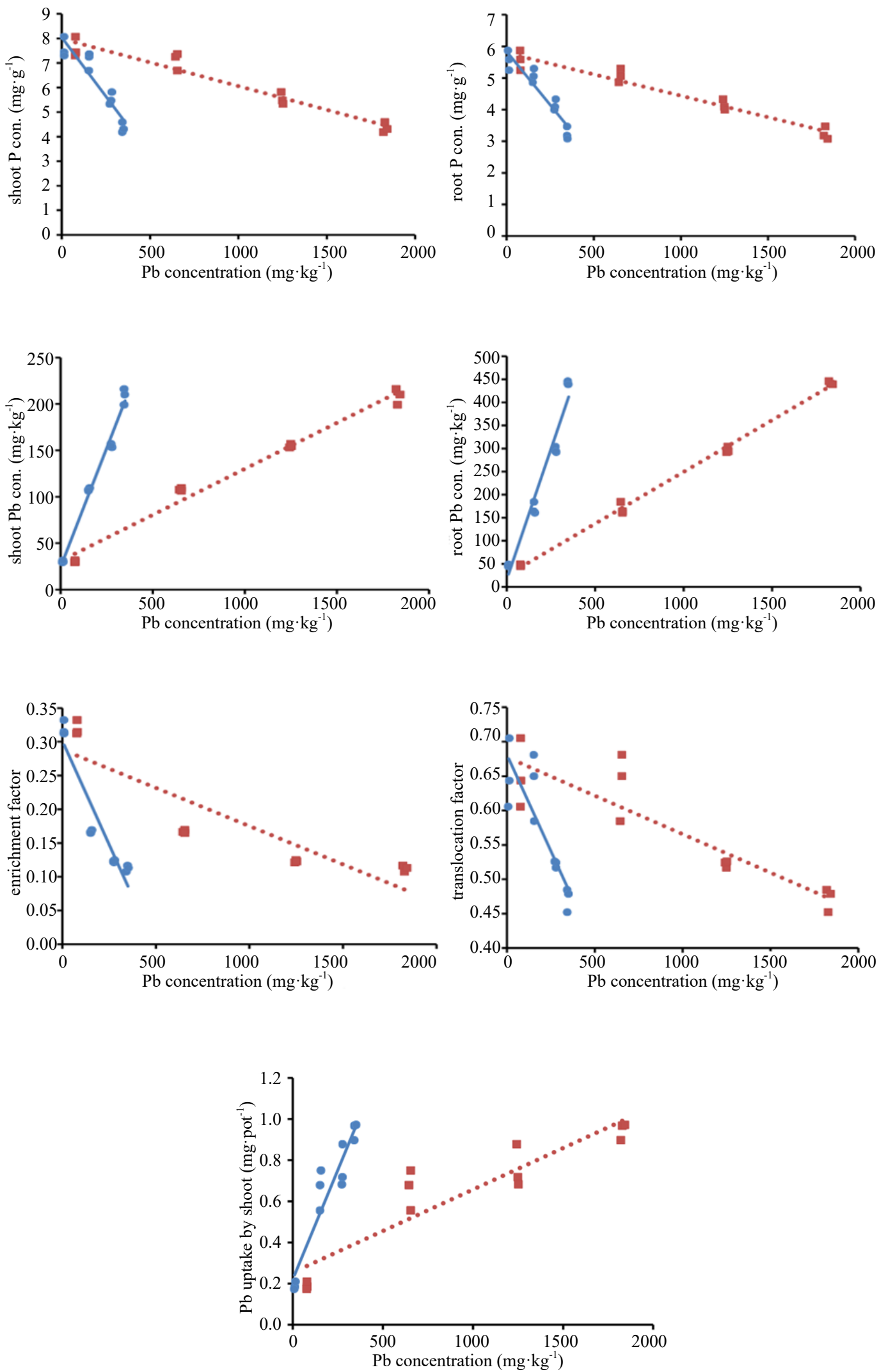

Figure 3. Simple linear regression between total and DTPA extractable $\mathrm{Pb}$ in soil and various phytoremediation indices by hemp 
As observed in this figure all phytoremediation indices have a steeper linear relation with DTPA extractable Pb rather than total $\mathrm{Pb}$. It indicates that the $\mathrm{DTPA}$ extractable $\mathrm{Pb}$ is more proper to evaluate $\mathrm{Pb}$ toxicity than the total forms in soil. Here with the increase of Pb levels, the negative effects of DTPA extractable $\mathrm{Pb}$ on phytoremediation indices are greater than those of total $\mathrm{Pb}$. In Figure 1, it can be seen that DTPA extractable $\mathrm{Pb}$ concentration increased with increase in $\mathrm{Pb}$ pollution but not at the same rate as the total $\mathrm{Pb}$. Hence, the bioavailable forms of heavy metals are more effective and more important than its total concentration. Due to precipitation of most of the total $\mathrm{Pb}$ that was added to the soil, especially in calcareous soils, usually its available form is toxic to living organisms. So DTPA extractable Pb compared with total extractable $\mathrm{Pb}$ in soil, has markedly higher direct and indirect effects on the phytoremediation indices. Earlier studies [62] reported the negative effect of different soil $\mathrm{Pb}$ fractions on diminishing soil biological properties. Soluble and labile fractions of $\mathrm{Pb}$ such as DTPA fraction had more effects on soil biological properties compared with residual and total fractions of $\mathrm{Pb}$ in soil.

Shoot and root dry weights, chlorophyll content, shoot and root phosphorus contents and enrichment and translocation factors, all showed negative regressions with soil $\mathrm{Pb}$ extracts. However, spore number, total shoot uptake of $\mathrm{Pb}$ and $\mathrm{Pb}$ concentration of root and shoot had positive regressions with soil $\mathrm{Pb}$ extracts. The percentage of vesicules in roots of hemp had negative regression with $\mathrm{Pb}$ levels in soil. It may due to harsh condition for plant to prepare sufficient organic carbon for mycobiont to produce and store fatty globules in vesicules. In contrast, arbuscules and hyphae percentage in roots of hemp had positive correlation coefficients with $\mathrm{Pb}$ levels in soil. Total root colonization similarly showed positive relation with soil $\mathrm{Pb}$ extracts. The higher root colonization and spore formation by AM fungi in hard condition was reported in many studies. Here the addition of Pb levels in soil increased the tendency of hemp for symbiosis with AM fungi and fungi spore formation.

\section{Conclusion}

The study of simple linear regression shows that DTPA extractable $\mathrm{Pb}$ had higher correlation coefficients with soil biological properties and plant indices for $\mathrm{Pb}$ phytoextraction. So it is a more proper index to evaluate heavy metals toxicity in soil compared to total concentration of heavy metals.

$\mathrm{Pb}$ concentration in shoot and root of hemps increased by AM fungi inoculation. Inoculation the hemp with Glomus species caused TF to decrease compared with non-inoculated ones, while resulting to higher dry biomass; so that total $\mathrm{Pb}$ uptake increased in inoculated hemps. Although inoculation of the hemp with G.constrictum caused higher $\mathrm{Pb}$ concentration in shoots, but with regard to the total $\mathrm{Pb}$ uptake, G.etunicatum is more proper for inoculation of hemp in phytoextraction of $\mathrm{Pb}$ from calcareous soils similar to the studied soil.

\section{Acknowledgements}

The authors would like to thank Bu Ali Sina University, Tabriz University, and Shahid Chamran University of Iran for their supporting in achieving this research.

\section{References}

[1] Chaney RL, Ryan JA. Risk based standards for arsenic, lead and cadmium in urban soils. Summary of information and methods developed to estimate standards for $\mathrm{Cd}$, Pb and As in urban soils. Dechema; 1994.

[2] Eick MJ, Peak JD, Brady PV, Pesek JD. Kinetics of lead adsorption/desorption on goethite: Residence time effect. Soil Science. 1999; 164: 28-39.

[3] Tang X, Yang J. Long-term stability and risk assessment of lead in mill waste treated by soluble phosphate. Science of the Total Environment. 2012; 438: 299-303.

[4] Sharma P, Dubey RS. Lead toxicity in plants. Brazilian. Journal of Plant Physiology. 2005; 17: 35-52.

[5] Angelone M, Bini C. Trace elements concentrations in soils and plants of Western Europe. In: Adriano DC. (ed.) Biogeochemistry of Trace Elements. Boca Raton, FL: Lewis Publishers; 1992. p.19-60. 
[6] Glick BR. Phytoremediation: Synergistic use of plants and bacteria to clean up the environment. Biotechnology Advances. 2003; 21: 383-393.

[7] Salt DE, Blaylock M, Kumar NPBA, Dushenkov V, Ensley BD, Chet I, et al. Phytoremediation: A novel strategy for the removal of toxic metals from the environment using plants. Natural Biotechnology. 1995; 13: 468-474.

[8] Del VC, Barea JM, Azcô̂n-Aguilar C. Assessing the tolerance to heavy metals of arbuscular mycorrhizal fungi isolated from sewage sludge-contaminated soils. Applied Soil Ecology. 1999; 11: 261-269.

[9] Göhre V, Paszkowski U. Contribution of the arbuscular mycorrhizal symbiosis to heavy metal phytoremediation. Planta. 2006; 223(6): 1115-1122.

[10] Miransari M. Hyperaccumulators, arbuscular mycorrhizal fungi and stress of heavy metals. Biotechnology Advances. 2011; 29(6): 645-653.

[11] Shahabivand S, Maivan HZ, Goltapeh EM, Sharifi M, Aliloo AA. The effects of root endophyte and arbuscular mycorrhizal fungi on growth and cadmium accumulation in wheat under cadmium toxicity. Plant Physiology and Biochemistry. 2012; 60: 53-58.

[12] Zafar S, Aqil F, Ahmad I. Metal tolerance and biosorption potential of filamentous fungi isolated from metal contaminated agricultural soil. Bioresource Technology. 2007; 98: 2557-2561.

[13] De-Andrade SA, da-Silveira AP. Mycorrhiza influence on maize development under Cd stress and P supply. Brazilian Journal of Plant Physiology. 2008; 20(1): 39-50.

[14] Liao JP, Lin XG, Cao ZH, Shi YQ, Wong MH. Interactions between arbuscular mycorrhizae and heavy metals under sand culture experiment. Chemosphere. 2003; 50: 847-853.

[15] Li XL, Christie P. Changes in soil solution $\mathrm{Zn}$ and $\mathrm{pH}$ and uptake of $\mathrm{Zn}$ by arbuscular mycorrhizal red clover in Zn-contaminated soil. Chemosphere. 2001; 42: 201-207.

[16] Hancock LM, Ernst CL, Charneskie R, Ruane LG. Effects of cadmium and mycorrhizal fungi on growth, fitness, and cadmium accumulation in flax (Linum usitatissimum; Linaceae). American Journal of Botany. 2012; 99: 14451452.

[17] Gu HH, Zhou Z, Gao YQ, Yuan XT, Ai YJ, Zhang JY, et al. The influences of arbuscular mycorrhizal fungus on phytostabilization of lead/zinc tailings using four plant species. International Journal of Phytoremediation. 2017; 19(8): 739-745.

[18] Zhang F, Liu M, Li Y, Che Y, Xiao Y. Effects of arbuscular mycorrhizal fungi, biochar and cadmium on the yield and element uptake of Medicago sativa. Sci Total Environ. 2018; 55: 1150-1158.

[19] Jiang L, Yang Y, Xu WH, Wang CL, Chen R, Xiong SJ, et al. Effects of ryegrass and arbuscular mycorrhiza on activities of antioxidant enzymes, accumulation and chemical forms of cadmium in different varieties of tomato. Huan. Jing. Ke. Xue. 2014; 35(6): 2349-2357.

[20] Wang L, Ji B, Hu Y, Liu R, SunW. A review on in situ phytoremediation of mine tailings. Chemosphere. 2017a; 184: 594-600.

[21] Wang W, Shi J, Xie Q, Jiang Y, Yu N, Wang E. Nutrient exchange and regulation in arbuscular mycorrhizal symbiosis. Molecular Plant. 2017; 10(9): 1147-1158.

[22] Zhong WL, Li JT, Chen YT, Shu WS, Liao B. A study on the effects of lead, cadmium and phosphorus on the lead and cadmium uptake efficacy of Viola baoshanensis inoculated with Arbuscular mycorrhizal fungi. Journal of Environmental Monitoring. 2012; 14(9): 2497-2504.

[23] Gaur A, Adholeya A. Prospects of arbuscular mycorrhizal fungi in phytoremediation of heavy metal contaminated soils. Current Science. 2004; 86: 528-534.

[24] Khan AG. Role of soil microbes in the rhizospheres of plants growing on trace metal contaminated soils in phytoremediation. Journal of Trace Elements in Medicine and Biology. 2005; 18(4): 355-364.

[25] Linger P, Mussig J, Fischer H, Kobert J. Industrial hemp (Cannabis sativa L.) growing on heavy metal contaminated soil: Fibre quality and phytoremediation potential. Industrial Crops and Products. 2002; 16: 33-42.

[26] Citterio S, Santagostino A, Fumagalli P, Prato N, Ranalli P, Sgorbati S. Heavy metal tolerance and accumulation of Cd, Cr and Ni by Cannabis sativa L. Plant Soil. 2003; 256(2): 243-252.

[27] Safari SAA, Mirahamdi AH. Effects of sterilization and temperature on the decrease kinetic of lead bioavailability in two different soil groups. Soil and Sediment Contamination: An International Journal. 2009; 18(6): 739-753.

[28] Giovannetti M, Mosse B. Evaluation of techniques for measuring vesicular arbuscular mycorrhizal infection in roots. New Phytologist. 1980; 84: 489-500.

[29] Sposito G, Lund LJ, Chang AC. Trace metal chemistry in arid-zone field soils amended with sewage sludge: I. fractionation of Ni, Cu, Zn, Cd, and Pb in solid phases. Soil Science Society of America Journal. 1982; 46: 260264. 
[30] Sastre JA, Sahuquillo MV, Rauret G. Determination of $\mathrm{Cd}, \mathrm{Cu}, \mathrm{Pb}$ and $\mathrm{Zn}$ in environmental samples: microwaveassisted total digestion versus aqua regia and nitric acid extraction. Analytica. Chimica. Acta. 2002; 462: 59-72.

[31] Lindsay WL, Norvell WA. Development of a DTPA Soil Test for Zinc, Iron, Manganese, and Copper1. Soil Science Society of America Journal. 1978; 42: 421-428.

[32] Safari SAA, Tahmasbian I, Sinegani M. Chelating agents and heavy metal phytoextraction. In: I. Sherameti, A. Varma. (eds.) Heavy Metal Contamination of Soils. Soil Biology. Springer International Publishing; 2015. p.367393.

[33] Lin CC, Liu J, Liu L, Zhu TC, Sheng LX, Wang DL. Soil amendment application frequency contributes to phytoextraction of lead by sunflower at different nutrient levels-Environ. Environmental and Experimental Botany. 2009; 65: 410-416.

[34] Olsen SR, Cole C, Watanabe FS, Dean L. Estimation of available phosphorus in soils by extraction with sodium bicarbonate. Washington, DC: US Department of Agriculture; 1954.

[35] Chapman HD, Pratt PF. Methods of analysis for soils, plants and waters. Division of Agricultural Sciences, University of California, Riverside; 1961.

[36] Punamiya P, Datta R, Sarkar D, Barber S, Patel M, Das P. Symbiotic role of Glomus mosseae in phytoextraction of lead in vetiver grass [Chrysopogon zizanioides (L.)]. Journal of Hazardous Materials. 2010; 177: 465-474.

[37] Shah K, Mankad AU, Reddy MN. Cadmium accumulation and its effects on growth and biochemical parameters in Tagetes erecta L. Journal of Pharmacognosy and Phytochemistry. 2017; 6: 111-115.

[38] Chang ZM, Wu XH. Difference comparison of three alfalfa varieties resistant to cadmium pollution. Prata. Cult. Sci. 2005; 22(12): 20-23.

[39] Citterio S, Prato N, Fumagalli P, Aina R, Massa N, Santagostino A, et al. The arbuscular mycorrhizal fungus Glomus mosseae induces growth and metal accumulation changes in Cannabis sativa L. Chemosphere. 2005; 59: 21-29.

[40] Cobbett CS. Heavy metal detoxification in plants: phytochelatin biosynthesis and function. IUBMB Life. 2001; 51: 183-188.

[41] Zhu YG. Christie P, Laidlaw AS. Uptake of Zn by arbuscular mycorrhizal white clover from Zn-contaminated soil. Chemosphere. 2001; 42: 193-199.

[42] Chen BD, Li XL, Tao HQ, Christie P, Wong MH. The role of arbuscular mycorrhiza in zinc uptake by red T. repens growing in a calcareous soil spiked with various quantities of zinc. Chemosphere. 2003; 50: 839-846.

[43] Xue ZC, Gao HY, Zhang LT. Effects of cadmium on growth, photosynthetic rate and chlorophyll content in leaves of soybean seedlings. Biologia Plantarum. 2013; 57(3): 587-590.

[44] Chen X, Wu C, Tang J, Hu S. Arbuscular mycorrhizae enhance metal lead uptake and growth of host plants under a sand culture experiment. Chemosphere. 2005; 60(5): 665-671.

[45] Ma MQ, Choate AL, Rao GN. Effects of incubation and phosphate rock on lead extractability and speciation in contaminated soils. Journal of Environmental Quality. 1997; 26: 801-807.

[46] Song H. Effects of VAM on host plant in the condition of drought stress and its mechanisms. Electronic Journal of Biology. 2005; 1(3): 44-48.

[47] Weissenhorn I, Leyval C, Berthelin J. Bioavailability of heavy metals and abundance of arbuscular mycorrhiza in soil polluted by atmospheric deposition from a smelter. Biology and Fertility in Soils. 1992; 19: 22-28.

[48] Pawlowska TE, Charvat I. Heavy metal stress and developmental patterns in arbuscular mycorrhizal fungi. Applied and Environmental Microbiology. 2004; 70(11): 6643-6649.

[49] Leyval C, Singh BR, Joner EJ. Occurrence and infectivity of arbuscular mycorrhizal fungi in some Norwegian soils influenced by heavy metals and soil properties. Water, Air, \& Soil Pollution. 1995; 84: 203-216.

[50] Malcová R, Vosátka M, Gryndler M. Effects of inoculation with Glomus intraradices on lead uptake by Zea mays L. and Agrostis capillaris L. Applied Soil Ecology. 2003; 23: 55-67.

[51] Wong CC, Wu SC, Kuek C, Khan AG, Wong MH. The role of mycorrhizae associated with vetiver grown in $\mathrm{Pb} /$ Zn-contaminated soils: Greenhouse study. Restoration Ecology. 2007; 15: 60-67.

[52] Joner EJ, Leyval C. Rhizosphere gradients of polycyclic aromatic hydrocarbon (PAH) dissipation in two industrial soils and the impact of arbuscular mycorrhiza. Environmental Science \& Technology. 2003; 37(11): 2371-2375.

[53] Liu H, Probst A, Liao B. Metal contamination of soils and crops affected by the Chenzhou lead/zinc mine spill (Hunan, China). Sci. Total. Environ. 2005; 339: 153-166.

[54] Wang Y, Shi J, Wang H, Lin Q, Chen X, Chen Y. The influence of soil heavy metals pollution on soil microbial biomass, enzyme activity, and community composition near a copper smelter. Ecotoxicology and Environmental Safety. 2007; 67(1): 75-81. 
[55] Zhao FJ, Hamon RE, Lombi E, Mclaughlin MJ, McGrath SP. Characteristics of cadmium uptake in two contrasting ecotypes of the hyperaccumulator Thlaspi caerulescens. Journal of Experimental Botany. 2002; 53: 535-543.

[56] Jasiewicz C, Baran A, Tarnawski M. Effect of bottom sediment on content, bioaccumulation and translocation of heavy metals in maize biomass. Journal of Elementology. 2010; 15: 281-290.

[57] Baker AJM, Brooks RR. Terrestrial higher plants which accumulate metallic elements-A review of their distribution-ecology and phytochemistry. Biorecovery. 1989; 1: 81-126.

[58] Zu YQ, Li Y, Chen JJ, Chen HY, Qin L, Christian S. Hyperaccumulation of Pb, Zn and Cd in herbaceous grown on lead-zinc mining area in Yunnan, China. Environment International. 2005; 31: 755-762.

[59] Singh R, Singh DP, Kumar N, Bhargava SK, Barman SC. Accumulation and translocation of heavy metals in soil and plants from fly ash contaminated area. Journal of Environmental Biology. 2010; 31(4): 421-430.

[60] Dickinson NM, Pulford ID. Cadmium phytoextraction using short-rotation coppice Salix: The evidence trail. Environment International. 2005; 31: 609-613.

[61] Khan AG, Kuek C, Chaudhry TM, Khoo CS, Hayes WJ. Role of plants, mycorrhizae and phytochelators in heavy metal contaminated land remediation. Chemosphere. 2000; 41: 197-207.

[62] Zalaghi R, Safari-sinegani AA. The importance of different forms of $\mathrm{Pb}$ on diminishing biological activities in a calcareous soil. Chemistry and Ecology. 2014; 30(5): 446-462. 